\title{
GAT-1, a High-Affinity GABA Plasma Membrane Transporter, Is Localized to Neurons and Astroglia in the Cerebral Cortex
}

\author{
Andrea Minelli, ${ }^{1}$ Nicholas C. Brecha, ${ }^{2,3,4,5,6}$ Christine Karschin, ${ }^{7}$ Silvia DeBiasi, ${ }^{8}$ and Fiorenzo Conti ${ }^{1}$ \\ 1'Institute of Human Physiology, University of Ancona, Ancona, Italy, ${ }^{2}$ Department of Neurobiology, ${ }^{3}$ Department of \\ Medicine, ${ }^{4}$ Brain Research Institute, and ${ }^{5}$ CURE:VA/UCLA Gastroenteric Biology Center, UCLA School of Medicine, \\ and ${ }^{6}$ Veterans Administration Medical Center, Los Angeles, CA, ${ }^{7}$ Max-Planck-Institute for Experimental Medicine, \\ Gottingen, Germany, and ${ }^{8}$ Department of General Physiology and Biochemistry, Section of Histology and Human \\ Anatomy, University of Milan, Milan, Italy
}

High affinity, GABA plasma membrane transporters influence the action of GABA, the main inhibitory neurotransmitter. The cellular expression of GAT-1, a prominent GABA transporter, has been investigated in the cerebral cortex of adult rats using in situ hybridizaton with ${ }^{35} \mathrm{~S}-\mathrm{la}-$ beled RNA probes and immunocytochemistry with affinity purified polyclonal antibodies directed to the C-termInus of rat GAT-1.

GAT-1 mRNA was observed in numerous neurons and in some glial cells. Double-labeling experiments were performed to compare the pattern of GAT-1 mRNA containing and GAD67 immunoreactive cells. The majority of neurons expressing GAT-1 mRNA also contained GAD67 immunoreactivity (ir), but GAT-1 mRNA was also observed in a few pyramidal neurons.

GAT-1-ir was localized to numerous puncta and fibers and to astrocytic processes, was not observed in sections incubated in GAT-1 antibodies preadsorbed with rat GAT-1 C-terminal peptide, and was observed in sections incubated in GAT-1 antibodies preadsorbed with the C-terminal portion of the related peptides rat GAT- $3_{607-627}$ or rat glycine transporter-1 $1_{625-633}$. The highest number of GAT-1-ir puncta was in layer IV, followed by layers II-III. GAT-1 positive puncta appeared to have a preferential relationship to the soma and proximal dendrites of unlabeled pyramidal cells. All GAT-1 positive axon terminals formed symmetric synapses.

This study demonstrates that (1) GAT-1 is expressed by both neurons and astrocytes, (2) the majority of GAT-1 expressing neurons contain GAD67, and (3) GAT-1 uptake system is more extensive than the GABA synthetizing system. These observations support the hypothesis that, in addition to its role in terminating GABA action by uptake

\footnotetext{
Received Mar. 31, 1995; revised July 6, 1995; accepted July 31, 1995.

This work was supported by a NATO Collaborative Research Grant (CRG 910273), and by funds from CNR (AI 90.01371 and 91.00731, CT04), MURST, NIH (EYO4067), VA Medical Research Funds, and Morphology Imaging CORE DK 41301. We thank Catia Sternini for her continuous support throughout the entire research project, and Lawrence Kruger for helpful discussions. We also thank J Guastella for GAT-1 cDNA, C. Evans for synthesis of the GABA and glycine C-terminal transporter peptides, and D. Su, T. Chen, and $\mathrm{K}$. Wen for assistance.

Correspondence should be addressed to Fiorenzo Conti, Istituto di Fisiologia Umana, Università di Ancona, Via Ranieri, Monte d'Ago, I-60131 Ancona, Italy.

Copyright (c) 1995 Society for Neuroscience $\quad 0270-6474 / 95 / 157734-13 \$ 05.00 / 0$
}

into GABAergic axon terminals, GAT-1 influences both excitatory and inhibitory transmission by modulating the "paracrine" spread of GABA (Isaacson et al., 1993), and suggest that astrocytes may play an important role in this process.

[Key words: GABA, GABA transporters, neocortex, synapses, neurons, astrocytes]

Synaptic transmission mediated by GABA plays a key role in controlling neuronal activity and information processing in the mammalian cerebral cortex (Krnjevic, 1984; Sillito, 1984; McCormick et al., 1993). The organization of the GABA system has been extensively studied, using immunocytochemistry (ICC) and in situ hybridization histochemistry (ISH) to visualize GABA or its synthetic enzymes, glutamic acid decarboxylase 65 and 67 (GAD65 and GAD67; Erlander et al., 1991). The availability of antibodies and cDNAs encoding GAD65 and 67 has allowed for a detailed characterization of the number, morphology, and distribution of cortical neurons synthetizing GABA and of their synapses (Ribak, 1978; Emson and Hunt, 1981; Houser et al., 1983, 1984; Somogyi and Martin, 1985; Fitzpatrick et al., 1987; Hendry et al., 1987; Freund and Meskenaite, 1992; Hendry and ('arder, 1992; Beaulieu, 1993; Jones, 1993). In general, GABA and GAD are expressed by nonpyramidal neurons that make symmetric synaptic contacts on the cell bodies and proximal dendrites of both pyramidal and nonpyramidal cells (Hendry and Carder, 1992; Jones, 1993). These observations have been complemented by defining the distribution of GABA receptor subunit mRNAs and proteins within the cortex (deBlas et al., 1988; Somogyi, 1989; Hendry et al., 1990; Huntley et al., 1990; Wisden et al., 1992; Gu et al., 1993; Huntsman et al., 1994).

Whereas much has been learnt about GABAergic neurons and synapses, little is known about the distribution of plasma membrane transporters that mediate GABA uptake into nerve endings and/or surrounding glial processes (Iversen and Neal, 1968; Iversen and Snyder, 1968; Neal and Iversen, 1969; Bloom and Iversen, 1970; Iversen, 1971; Hokfelt and Ljungdahl, 1972; Iversen and Kelly, 1975; Kanner, 1978; Schousboe, 1981; Kanner and Shuldiner, 1987; Radian et al., 1990). GABA transporters play an important role in the regulation of the magnitude and duration of GABA's action (Isaacson et al., 1993; Mager et al., 1993) and may also release $\mathrm{GABA}$ into the extracellular space in a $\mathrm{Ca}^{2+}$ independent, nonvesicular manner (Schwartz, 1982; Pin and Bockaert, 1989; Attwell et al., 1993; Levi and Raiteri, 1993). 

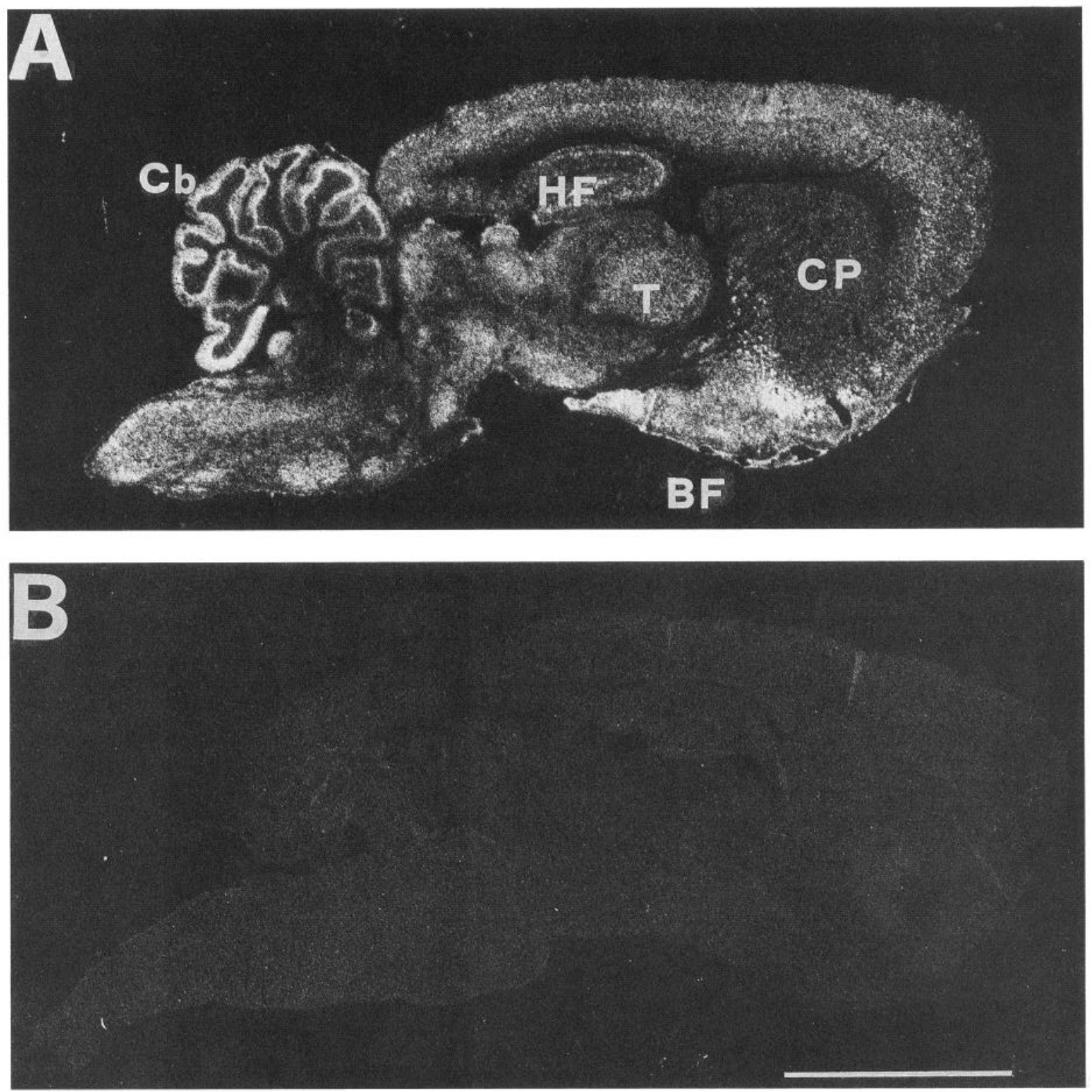

Figure 1. A, Distribution of GAT-1 mRNAs in a parasagittal section of an adult rat, incubated with the antisense GAT-1 RNA probe and exposed for $15 \mathrm{~d}$. Note the high levels of hybridization signal in brainstem, basal forebrain, cerebellum, and cerebral neocortex. $B$, A corresponding section processed with the sense GAT-1 RNA probe and exposed for $15 \mathrm{~d}$. Scale bar, $5 \mathrm{~mm}$.

Four cDNAs encoding GABA transporters (GATs) have been localized in the rodent and human nervous system (Guastella et al., 1990; Borden et al., 1992; Brecha et al., 1992; Clark et al., 1992; Liu et al., 1993; Borden et al., 1994a). These transporters share a high degree of nucleotide and amino acid sequence homology, and they transport GABA in a high affinity, $\mathrm{Na}^{+}$and $\mathrm{Cl}^{-}$dependent manner, but they differ in their tissue distribution (Borden et al., 1992; Ikegaki et al., 1994; Brecha et al., 1995) and pharmacological properties (Guastella et al., 1990; Borden et al., 1992; Brecha et al., 1992; Clark et al., 1992; Liu et al., 1993). GABA uptake by GAT-1 is strongly inhibited by cis-3aminocyclohexane carboxylic acid (ACHC) and, to a lesser extent, by 2,4 -diaminobutyric acid, but not by $\beta$-alanine (Guastella et al., 1990; Keynan et al., 1992). These properties are often considered typical of "neuronal" transporters (Beart et al. 1972; Iversen and Kelly, 1975; Bowery et al., 1976; Larsson et al.,
1983; Mabjeesh et al., 1992). In contrast, GAT-2 and GAT-3 exhibit pharmacological properties often associated with "glial" transporters (Schon and Kelly, 1974; Iversen and Kelly, 1975; Gavrilovic et al., 1984; Kanner and Bendahan, 1990; Mabjeesh et al., 1992), since GABA uptake by GAT-2 and GAT-3 is strongly inhibited by $\beta$-alanine, but not by ACHC (Borden et al., 1992; Clark et al., 1992; Clark and Amara, 1994). GABA uptake by the fourth GABA transporter, BGT-1, is not inhibited by ACHC or $\beta$-alanine (Yamauchi et al., 1992; Liu et al., 1993).

There is little information concerning the cellular expression of GATs in the cerebral cortex; GAT-1 expression is prominent, whereas GAT-3 expression is very low, and GAT-2 expression is absent (Brecha et al., 1992, 1993, and unpublished observations; Clark et al., 1992; Ikegaki et al., 1994; Kruger et al., 1994; Swan et al., 1994). In this study, we have used ISH with GAT-1 RNA probes and ICC with affinity purified GAT-1 antibodies 


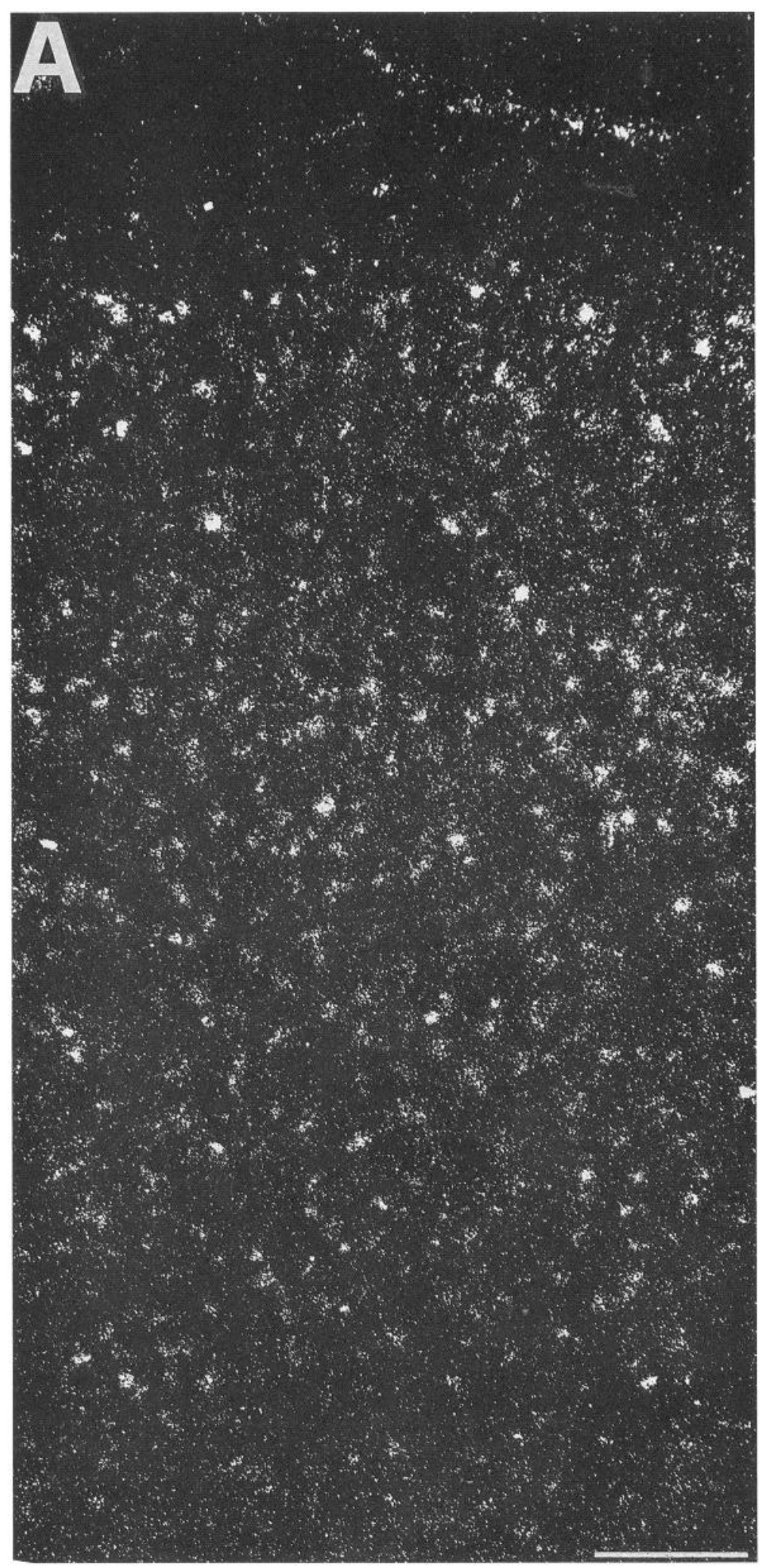

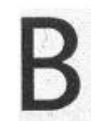
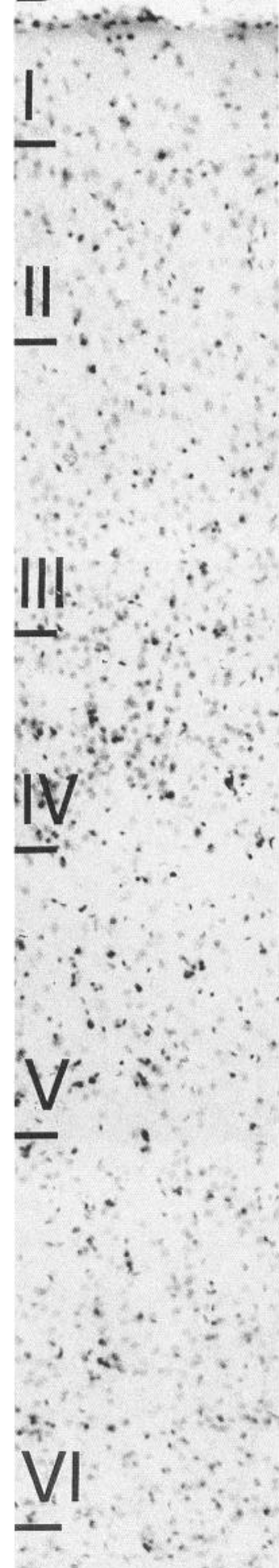

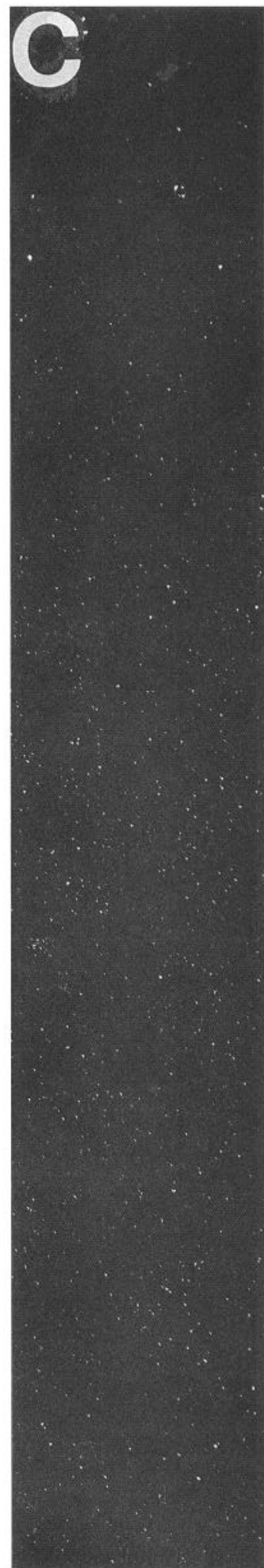

Figure 2. A, Localization of GAT-1 transcripts in the first somatic sensory cortex of an adult rat. Note the high level of hybridization signal in layer IV. $B$, The same section shown in $A$ after thionin staining. Roman numerals indicate cortical layers. $C$, Distribution of GAT-1 transcripts in a section of cortex processed with the sense GAT-1 RNA probe. Scale bar, $150 \mu \mathrm{m}$. 


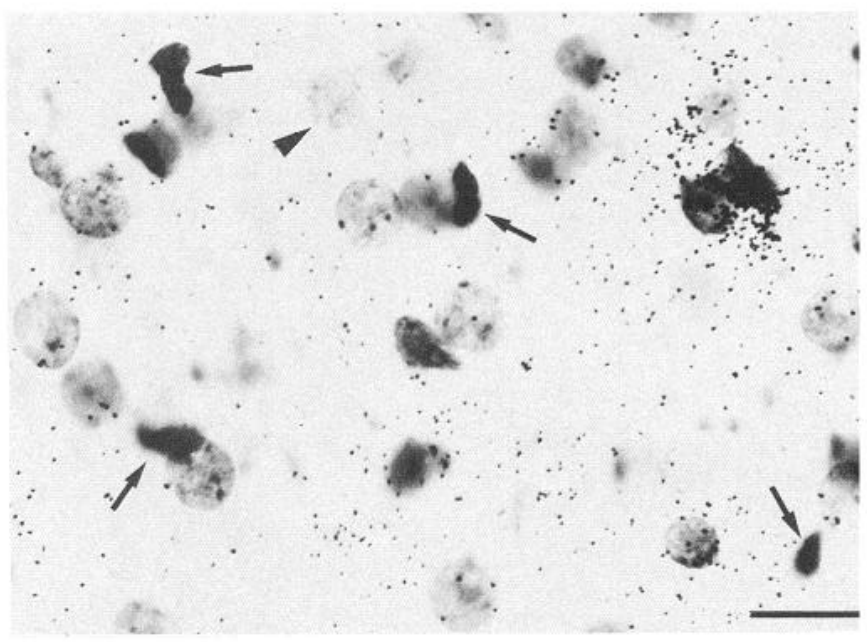

Figure 3. Layer III of SI showing that labeled cells contain variable levels of GAT-1 mRNA. All of the small and darkly stained cells (arrows) present in this field are negative, whereas neurons (arrowhead) display a variable number of silver grains. Scale bar, $25 \mu \mathrm{m}$.

(Brecha et al., 1993; Johnson et al., 1995, unpublished observations) to determine the cellular distribution of GAT-1 in the cerebral cortex of adult rats.

Preliminary results have been presented in abstract form (Minelli et al., 1993).

\section{Materials and Methods}

\section{Tissue preparation}

Adult albino rats (Sprague-Dawley; Harlan, San Diego, CA), weighing 180-250 gm, were used in the present studies. Care and handling of animals were approved by the Animal Research Committee of the VAMC-West Los Angeles in accordance with all NIH guidelines. Rats were deeply anesthetized with $30 \%$ cloral hydrate and perfused transcardially with $0.01 \mathrm{M}$ or $0.1 \mathrm{M}$ phosphate-buffered saline $(\mathrm{pH} 7.4)$ followed by $4 \%$ paraformaldehyde (PFA) in $0.1 \mathrm{M}$ phosphate buffer (PB). For electron microscopy, rats were perfused with $4 \%$ PFA plus $0.25 \%$ glutaraldehyde in PB. Brains used for ISH were stored in a solution of $20 \%$ sucrose in $4 \%$ PFA at $4^{\circ} \mathrm{C}$, whereas brains used for both light and electron microscopy ICC were postfixed for $1-2 \mathrm{hr}$ in $4 \%$ PFA and then stored in $20 \%$ sucrose in $\mathrm{PB}$ at $4^{\circ} \mathrm{C}$. Brains were cut with a microtome or vibratome in either coronal or parasagittal plane into $20-35$ or 50 $100 \mu \mathrm{m}$ thick sections, respectively. Sections were stored at $4^{\circ} \mathrm{C}$ in PFA until processing for ISH, and in PB for ICC.

Data and illustrations were collected from a region of the parietal cortex characterized by the presence of a conspicuous layer IV, with intermingled dysgranular regions, densely packed layers II and III, and a relatively cell-free layer Va. This area corresponds to the first somatic sensory cortex (SI; Zilles, 1985; Chapin and Lin, 1990).

\section{In situ hybridization histochemistry}

ISH procedure. A $4.2 \mathrm{~kb}$, full length rat GABA transporter cDNA clone (Guastella et al., 1990) was used in these experiments. Antisense and sense riboprobes were transcribed in vitro using $\mathrm{T} 3$ or $\mathrm{T} 7$ polymerase and ${ }^{35} \mathrm{~S}$-uridine triphosphate $(1,200 \mathrm{mCi} / \mathrm{mmol}$; NEN/Du Pont, Wilmington, DL) at a specific activity of $3-5 \times 10^{8} \mathrm{cpm} / \mu \mathrm{g}$. Full length and partially digested RNA probes (Cox et al., 1984) were used for the ISH experiments.

The ISH protocols were similar to that described in previous publications (Brecha et al., 1989; Sternini et al., 1989; Conti et al., 1994a,b). Free floating sections were washed with glycine $(0.75 \mathrm{mg} / \mathrm{ml}) / \mathrm{PBS}$ and with $2 \times \operatorname{SSC}(0.2 \mathrm{M} \mathrm{NaCl}, 0.2 \mathrm{M} \mathrm{NaCitrate})$, incubated in proteinase $\mathrm{K}(1 \mu \mathrm{g} / \mathrm{ml})$ for $30 \mathrm{~min}$ at $37^{\circ} \mathrm{C}$ followed by triethanolamine $(\mathrm{pH} 8)$ plus acetic anhydride for $10 \mathrm{~min}$ and then rinsed in $2 \times \mathrm{SSC}$. Sections were prehybridized at $37^{\circ} \mathrm{C}$ for $2 \mathrm{hr}$ with hybridization mixture $(25 \mathrm{~mm}$ PIPES, pH 6.8, $0.75 \mathrm{M} \mathrm{NaCl}, 25 \mathrm{~mm}$ EDTA, $1 \times$ Denhardt's solution (0.02\% PVP, $0.02 \%$ Ficoll, $0.02 \%$ BSA), $50 \%$ deionized formamide,
$0.2 \%$ sodium dodecyl sulfate, $100 \mathrm{~mm}$ dithiothreitol, $250 \mu \mathrm{g} / \mathrm{ml}$ denatured salmon sperm DNA, and $250 \mu \mathrm{g} / \mathrm{ml}$ polyadenylic acid). Sections were then incubated in the hybridization mixture with $5 \%$ dextran sulfate and full length (or partially digested) ${ }^{35} \mathrm{~S}$-GAT-1 sense or antisense RNA probes $(0.1 \mathrm{ng} / \mu \mathrm{l})$ overnight at $55^{\circ} \mathrm{C}$. Sections were rinsed in 4 $\times$ SSC containing $50 \mathrm{~mm} \beta$-mercaptoethanol and $10 \mathrm{~mm} \mathrm{NaS}_{2} \mathrm{O}_{3}$, incubated in pancreatic RNase A $(50 \mu \mathrm{g} / \mathrm{ml})$ for $30 \mathrm{~min}$ at $37^{\circ} \mathrm{C}$, washed with SSC buffer at increasing stringency to a final wash of $0.1 \times$ SSC at $55-65^{\circ} \mathrm{C}$, and then rinsed overnight in $0.1 \times \mathrm{SSC}$ at room temperature and mounted on slides. Sections were dehydrated through graded ethanols, air dried, and exposed to Kodak XAR x-ray film for 2-4 d. Sections were then coated with Kodak NTB-2 liquid photographic emulsion diluted 1:1 with water. Autoradiograms were developed in Kodak D-19 and fixed in Kodak fixer after $10-20 \mathrm{~d}$ of exposure at $4^{\circ} \mathrm{C}$. Finally, sections were counterstained with toluidine blue, dehydrated, cleared in xylene and coverslipped.

ISH/ICC experiments. Several series of sections were processed by ISH and by ICC with antibodies directed to glial fibrillary acidic protein (GFAP, Sigma, Saint Louis, MO; Eng, 1971; Bignami and Dahl, 1973) or to GAD67 (K2; Kaufman et al., 1991). These sections were first processed for ISH as described above, and after the final wash in 0.1 $\times$ SSC they were washed in PB, incubated for $30 \mathrm{~min}$ in normal goat serum (NGS; $1 \%$ for GFAP and 10\% for GAD67) and overnight in GFAP or GAD67 antibodies (dilution: 1:100-200 for GFAP, 1:2000 for GAD67; in $0.1 \mathrm{M} \mathrm{PB}$ at $4^{\circ} \mathrm{C}$ ). Sections were rinsed in $\mathrm{PB}$, incubated in NGS for $15 \mathrm{~min}$ and then in biotinylated goat anti-mouse (for GFAP) or anti-rabbit IgG (for GAD67) at a dilution of 1:100 for 1-2 hr at room temperature. Sections were rinsed in $\mathrm{PB}$, incubated in avidin-biotin peroxidase complex (ABC; Hsu et al., 1981) for $1 / 2 \mathrm{hr}$, and rinsed in PB Sections were then incubated in $50-75 \mathrm{mg} / 100 \mathrm{ml}$ of $3-3^{\prime}$-diaminobenzidine (DAB; Sigma, St. Louis, MO) and then in fresh DAB with $0.02 \% \mathrm{H}_{2} \mathrm{O}_{2}$. Sections were then rinsed in $\mathrm{PB}$, mounted on gelatincoated slides, air-dried, processed for autoradiography (as described above), and coverslipped. To determine if the two procedures interfered with each other, 10 sections of each experimental series were processed for ISH, and 10 sections (from the same animal) were processed for ICC. These sections processed by ISH/ICC, ISH, and ICC did not show any differences in the intensity and distribution of hybridization signal, or in the number of GFAP- or GAD67-positive cells. In addition, in our experimental conditions, the morphology and distribution of GFAP- or GAD67-positive cells were similar to those previously reported (Bignami and Dahl, 1973; Ribak, 1978; Houser et al., 1984; Herrera and Cuello, 1992).

Data analysis. In our experimental conditions, autoradiograms exposed for $15 \mathrm{~d}$ showed the best signal/noise ratio and were therefore used for evaluating GAT-1 mRNA expression. A cell was considered "associated with grains," when silver grains were clustered over and immediately adjacent to the cell body. Sections incubated with sense RNA probes were used to evaluate and determine background levels, that were set at the mean number of silver grains/cell plus 2 SDs. Cells were considered positive when the number of silver grains they were associated with was higher than background level.

\section{Immunocytochemistry}

Antibodies. Affinity purified polyclonal antibodies (341-F and 346-J) directed to the predicted C-terminus (Guastella et al., 1990) of rat GAT-1 (rGAT- $1_{588-599}$ ) were used for these studies. Synthetic rat GAT$1_{588-599}$ was coupled to keyhole limpet hemocyanin (KLH) with glutaraldehyde. Rabbits were initially immunized with $100 \mathrm{nmol}$ of the GAT$1_{588-599}$ conjugated to KLH in complete Freund's adjuvant, and subsequentely immunized at 4-6 weekly intervals with $50 \mathrm{nmol}$ of the GAT$1_{588-599}$ conjugated to KLH conjugate in incomplete Freund's adjuvant. Plasma was collected after each immunization, separated and antisera were affinity purified using an Epoxy-Sepharose-GAT- $1_{\text {588-599 }}$ affinity column (Pharmica Biotech, Picataway, NJ). Purified antibodies were concentrated and stored in $0.1 \mathrm{M}$ PB with $1 \% \mathrm{BSA}$ and $0.1 \% \mathrm{NaN}_{3}$ at $4^{\circ} \mathrm{C}$ or $-70^{\circ} \mathrm{C}$.

GAT-1 antibodies have been characterized by immunoblocking with different predicted C-terminal peptides of cloned GABA and glycine (GLY) transporters. GAT-1 immunostaining is prevented in rat central nervous system and retina when GAT-1 antibodies were adsorbed with $10^{-5} \mathrm{M}$ or $10^{-6} \mathrm{M}$ rat GAT- $1_{588-599}$. Specific GAT-1 immunostaining is unchanged in sections incubated with GAT-1 antibodies adsorbed with $10^{-5} \mathrm{M}$ rat GAT- $3_{607.627}$, mouse GAT- $2_{593-602}$, and rat GLYT- ${ }_{625-633} \mathrm{C}$ terminal peptides (Guastella et al., 1990, 1992; Borden et al., 1992; Liu 
Figure 4. Simultaneous visualization of GFAP (diffuse staining) and GAT-1 mRNA (granules) shows that some GFAP-positive cells express GAT-1 mRNA. Arrow points to a positive astrocyte in layer III of rat SI, arrowhead to a cluster of grains not associated with astrocytes. Exposure time, $15 \mathrm{~d}$. Scale bar, $15 \mu \mathrm{m}$.

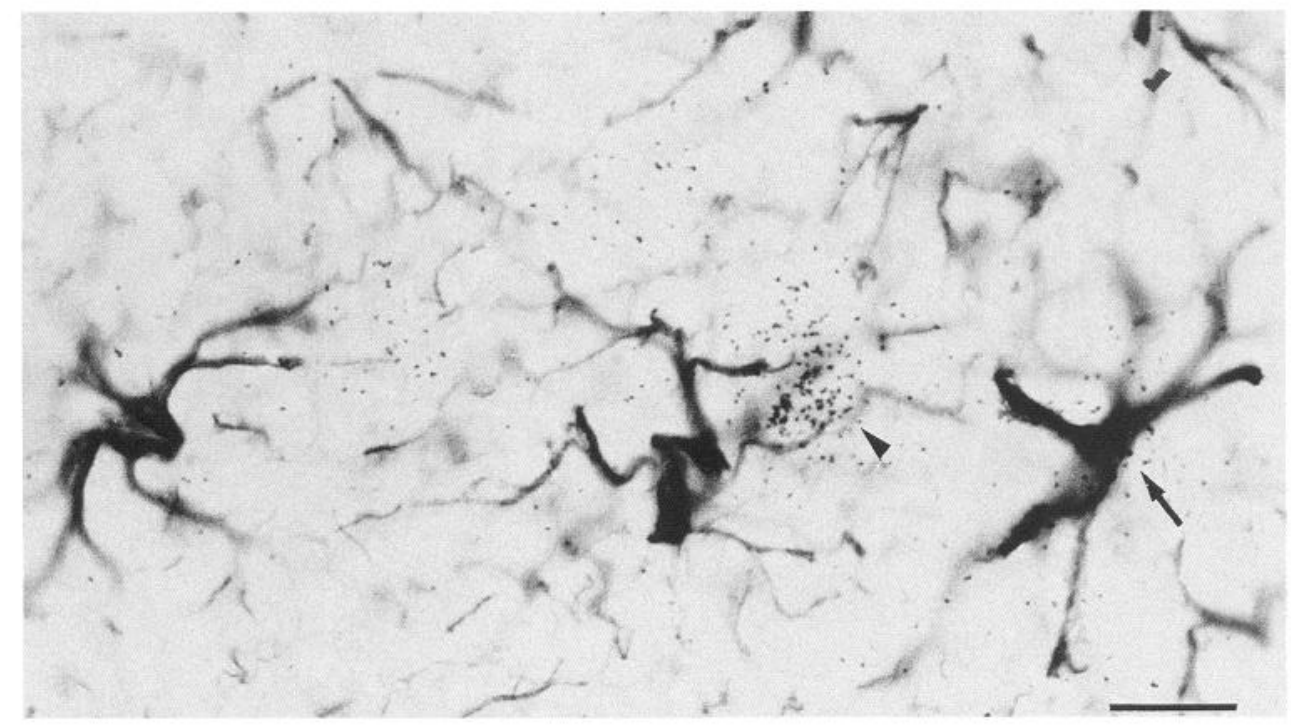

et al., 1993). These peptides were used because of possible cross-reactivity with rat GAT- $1_{588-599}$.

Polyclonal antibodies to GAD67 (K2) used in the present study have been previously characterized (Kaufman et al., 1991).

Procedure. Coronal and parasagittal free floating sections were washed in $\mathrm{PB}$, and incubated overnight in primary antiserum at a dilution of $1: 500$ to $1: 2000$ in PB containing $10 \%$ normal goat serum (NGS) and $0.5 \%$ Triton X-100 at $4^{\circ} \mathrm{C}$. Sections were rinsed, incubated in biotinylated anti-rabbit IgG at a dilution of 1:100 in PB for about 1$2 \mathrm{hr}$ at room temperature, rinsed in $\mathrm{PB}$, and then incubated in $\mathrm{ABC}$ and $\mathrm{DAB}$ as described above. Sections were then washed in PB, mounted on subbed slides, air dried, incubated in $0.02 \% \mathrm{OsO}_{4}$ for $10-20 \mathrm{sec}$, washed, dehydrated, and finally coverslipped.

For electron microscopy, a mild ethanol pretreatment $(10 \%, 25 \%$, $10 \% ; 5$ min each) was used before the ICC procedure. The antibody was diluted 1:700 and Triton X-100 was not used. After completion of the ICC procedure, sections were washed in PB, postfixed in $2.5 \%$ glutaraldehyde (30 min), washed in PB, and postfixed for $1 \mathrm{hr}$ in $1 \%$ $\mathrm{OsO}_{4}$. After dehydration in ethanol and infiltration in Epon-Spurr resin, sections were flat embedded between two Sigmacote (Sigma, 8F119)coated coverslips. Small blocks, selected by light microscopical inspection, were cut out, glued to blank cured epoxy, and sectioned with an ultramicrotome. Thin sections were lightly stained with lead citrate or left unstained and examined in a Jeol TEM8 electron microscope.

\section{Results}

\section{Cellular localization and laminar distribution of neurons expressing GAT-1 $\mathrm{mRNA}$}

GAT-1 mRNA was widely distributed in the central nervous system; the highest levels of hybridization signal were observed in many brainstem nuclei, including the superior and inferior colliculi, ventral tegmental area, pontine nuclei, and inferior olive, and in the cerebellum, thalamus, basal forebrain, hippocampus, olfactory bulb and neocortex (Fig. 1). In the cerebral cortex, GAT-1 mRNA was widely and heterogeneously distributed, and there is an increased level of hybridization signal in layer IV and, to a lesser extent, in layer II.

In tissue sections incubated with sense RNA probes and exposed for $15 \mathrm{~d}$, labeling was characterized by a very low density of silver grains distributed evenly in all cortical layers (Fig. 2C). Sections incubated with the antisense probe, coated with photographic emulsion and exposed for $15 \mathrm{~d}$, showed that GAT-1 mRNAs were present in all cortical layers, with layers IV and II exhibiting the highest level of hybridization signal (Fig. 2A,B). Positive cells were associated with a variable number of silver grains (Fig. 3).
The large majority of negative cortical cells were small (major diameter: $4-8.3 \mu \mathrm{m}$; mean value: $6.1 \mu \mathrm{m} ; N=100$ ) and they usually were darkly stained with toluidine blue (Fig. 3), although some of these cells were associated with grains. Since the soma size, staining properties and distribution of these cells is suggestive of neuroglia, and in particular of astrocytes, we directly evaluated whether astrocytes express GAT-1 mRNA by a double labeling approach in which ISH was combined with ICC with antibodies to GFAP. The results of this series of experiments showed that most GFAP-positive cells were negative, although some express GAT-1 mRNA (Fig. 4).

Cells whose major diameter was larger than astrocytes were considered neurons; these cells were the large majority of positive cells and were present in all layers. We evaluated next the degree of coexpression of GAT-1 mRNA and GAD67 immunoreactivity. All GAD67-positive cells were GAT-1-positive (Fig. 5). However, not all cells expressing GAT-1 mRNA were GAD67-positive. A few neurons, including some pyramidal neurons, were GAD67-negative, but they expressed GAT-1 mRNA (Fig. 5A). Because of the difficulty of identifying pyramidal neurons in these preparations, we evaluated these cells in layer $\mathrm{V}$ since they could be identified by the presence of numerous GAT-1 positive puncta covering their cell bodies. In each microscopic field centered on layer $\mathrm{V}$, one or two pyramidal neurons expressed GAT-1 mRNA.

\section{Distribution and localization of GAT-1 immunoreactivity}

Specific GAT-1 immunoreactivity.(ir) was present in all cortical layers and in the underlying white matter. GAT-1 ir was associated with punctate structures, which appeared to be axon terminals, and radially oriented fibers, but not with cell bodies (Figs. 6, 8); GAT-1-positive fibers were also observed in the underlying white matter and were particularly numerous in the corpus callosum. Specific immunostaining was not observed in control sections incubated with GAT-1 antibodies adsorbed with rat GAT- $1_{588-599}$ (Fig. $7 C$ ). No changes in immunostaining patterns were seen in sections incubated in GAT-1 antibodies that were adsorbed with GAT-3 or GLYT-1 C-terminal peptides (Fig. $7 A, B)$.

The same pattern of GAT-1-positive puncta was observed in all sections from several animals. Furthermore, comparable im- 

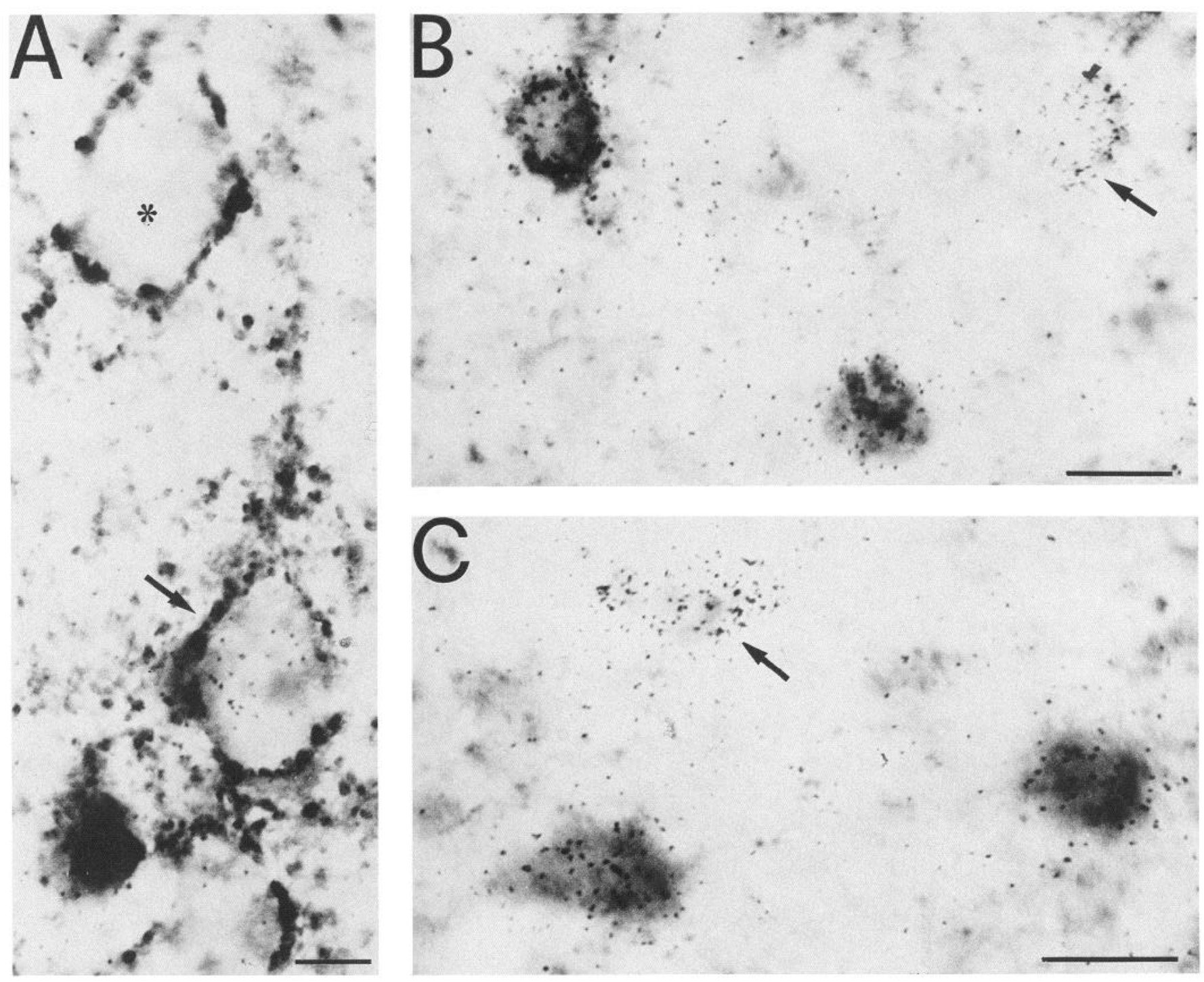

Figure 5. Simultaneous visualization of GAD67-ir and GAT-1 mRNA in rat cerebral cortex shows that all GAD67-positive cells express GAT-1 mRNA, but that not all GAT-1 mRNA expressing cells contain GAD67-ir (arrows). Of these, some are pyramidal neurons, as revealed by the dense clustering of GAD67-positive axon terminals on their somata and proximal dendrites $(A)$. In $A$, asterisk indicates a pyramidal neuron not expressing GAT-1 mRNA. Exposure time: 15 d. $A$, Layer V; $B$ and $C$, II. Scale bars: $20 \mu \mathrm{m}$.

munostaining patterns were also observed in all cortical areas. The following description of the immunostaining pattern is from SI cortex.

GAT-1-positive puncta were relatively sparse in layer I, although the most superficial portion of this layer contained numerous puncta and horizontally or obliquely oriented fibers (Figs. 6A, 8C,D). Layers II-III (especially the lower portion of the latter) contained numerous immunoreactive puncta and fibers (Fig. 6). Layer IV showed the highest level of intensely stained and densely packed puncta (Fig. 6). Overall, infragranular layers exhibited a much lower intensity of staining than layer IV or supragranular layers (Fig. 6). However, a band of increased intensity of staining was over the lower portion of layer $\mathrm{V}$ (layer Vb; Fig. 6A). Numerous immunoreactive fibers, usually running obliquely or radially and showing irregularly spaced varicose swellings, were observed in infragranular layers, particularly in layer VI (Fig. 8D).

GAT-1-positive puncta were observed throughout the neuropil and they appeared to have a preferential relationship to the soma and proximal dendrites of cortical neurons (Figs. 6, 8A,B). Puncta were so numerous around some neuronal perikarya that they appeared to form continuous sheets (Fig. $8 A, B$ ). In layers II--III and V-VI, numerous GAT-1-positive puncta were observed around the somata and the proximal portions of the apical dendrites of pyramidal cells (Fig. 8A,B), although GAT-1-positive puncta were also observed in close apposition with distal dendrites (Fig. 8). In the majority of the cases, the distribution of the GAT-1-positive puncta distinctly outlined unlabeled pyramidal cells. GAT-1-positive puncta were, however, also noted around cells that did not have the appearance of pyramidal cells (Fig. 8). In layer IV, GAT-1-positive puncta formed clear outlines of numerous round, small-sized and densely packed cells, which are likely to be nonpyramidal neurons.

The distribution of GAT-1 and GAD67 ir were directly compared in adjacent sections. The distribution of GAD67 ir in SI of a non-colchicine-treated adult rat (Fig. 6C) is in agreement with previous descriptions (Houser et al., 1984; Esclapez et al., 1994). The patterns of distribution of GAD67- and GAT-1-pos- 


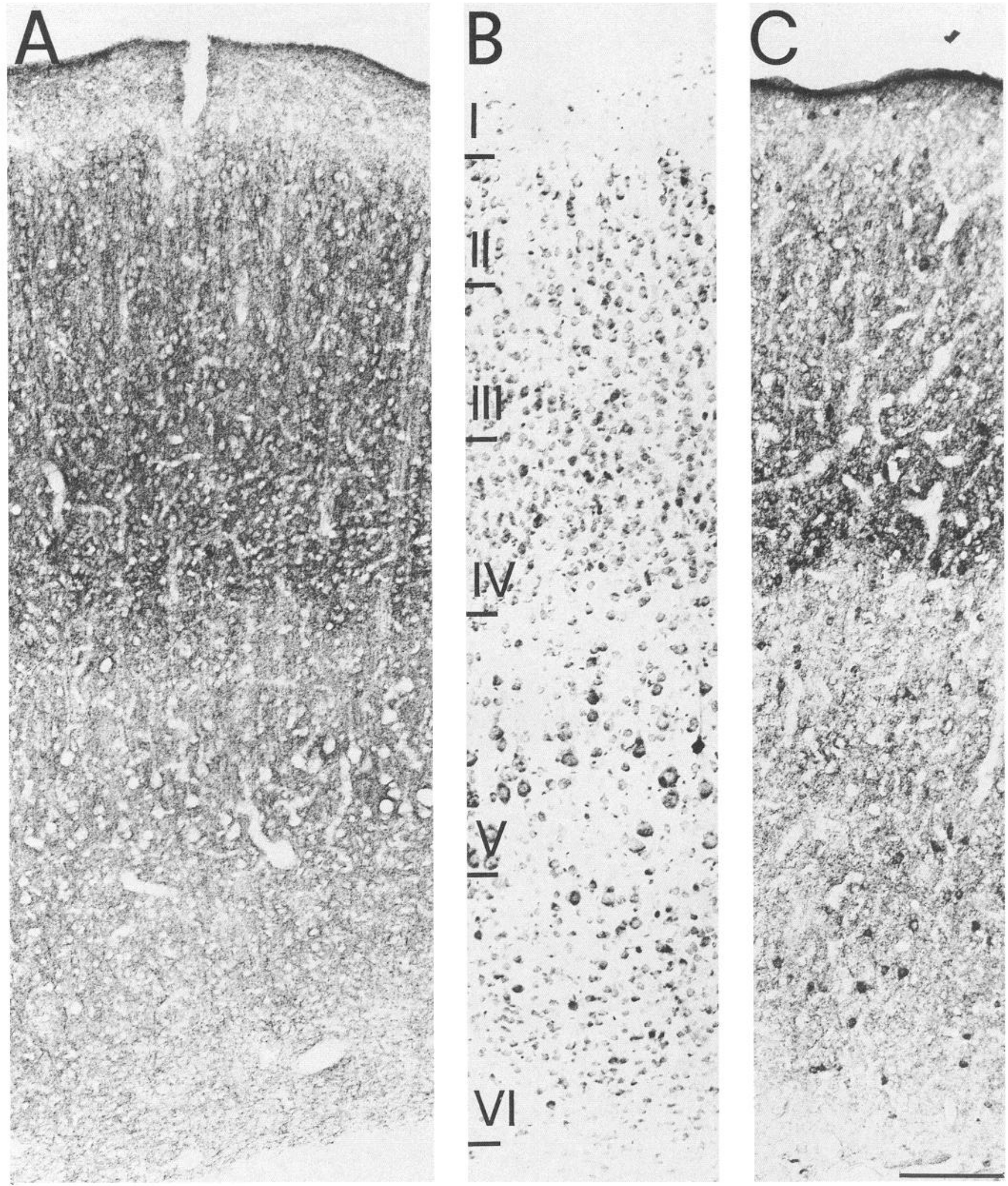

Figure 6. A, Distribution of GAT-1 immunoreactivity in SI of adult rats. B, Adjacent Nissl stained section. Roman numerals indicate cortical layers. $C$, distribution of GAD67-positive axon terminals and neurons. Scale bar, $150 \mu \mathrm{m}$. 

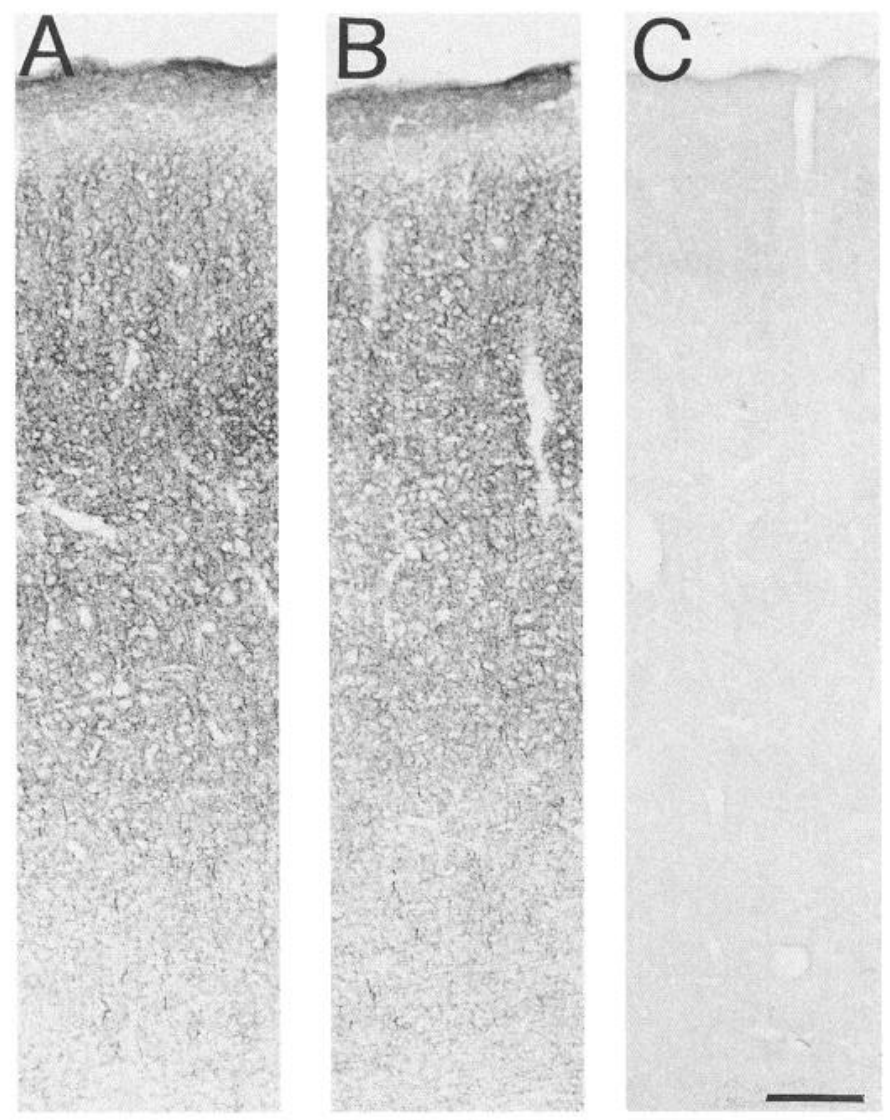

Figure 7. GAT-1 immunoreactivity does not change following preincubation with $10^{-5} \mathrm{M}$ rat GAT- $3_{607-627}(A)$, or rat GLYT- $1_{625-633}(B)$, but it is completely abolished following incubation in GAT-1 antibody preadsorbed with $10^{-5} \mathrm{M}$ rat GAT-1 $1_{588-599}(C)$. Scale bar, $150 \mu \mathrm{m}$.

itive puncta are remarkably similar, with the exception that GAT-1 ir is more evident than GAD67 ir in layers II-III. Furthermore, there is a similar relationship between GAD67- and GAT-1-positive puncta with neuronal perikarya and proximal dendrites (Fig. $8 A, B$; see Ribak, 1978, and Houser et al., 1984).

The ultrastructural pattern of labeling for GAT-1 was similar in all layers of the cortex. Immunostaining, in the form of electron dense reaction product, was mostly found in axonal and glial profiles, whereas somata and dendrites were unlabeled (Fig. 9). Axonal labeling was present in the axoplasm of thinly myelinated axons (Fig. 9A) and in numerous presynaptic axon terminals (Fig. 9B-D). Labeled terminals were heterogeneous in size and shape, but all formed symmetrical synaptic contacts (Fig. 9B-D). The profiles postsynaptic to the immunopositive terminals were unlabeled cell bodies (Fig. $9 B$ ) or dendrites of all sizes (Fig. 9C,D). Adjacent terminals with asymmetric synaptic specialization were always unlabeled (Fig. 9B-D). Reaction product was also found in distal astrocytic processes (Fig. $9 E-G)$, identified by the tortuous plasma membrane that interleaves among unlabeled axonal and dendritic profiles (Fig. 9E, F) or by their perivascular position (Fig. $9 G$ ). Astrocytic cell bodies, oligodendrocytes and microglial cells were unlabeled. Occasionally, weak immunolabeling (not illustrated) was observed in the cytoplasm of cell bodies characterized by nuclear infoldings and along the membranes of their organelles, particularly Golgi cisterns. Analysis of sections reacted with the GAT-1 antibody preadsorbed with $10^{-5} \mathrm{M}$ rat GAT- $3_{607-627}$ showed that the pattern of ir was identical to that observed in sections processed with the GAT-1 antibody.

\section{Discussion}

GAT-1 is prominently expressed in the neocortex of adult rats, and it is localized to both neurons and astrocytic processes. The majority of neurons expressing GAT-1 mRNA contain GAD67 immunoreactivity and are the source of GAT-1 immunoreactive axon terminals forming symmetric synapses. However, a few pyramidal cells also express GAT-1 mRNA. These results indicate that the magnitude of the cortical GABA uptake system is more extensive than previously believed and suggest that the GAT-1 uptake system may have important regulatory roles which would influence cortical information processing.

\section{GAT-1 expression in cortical astrocytes}

Numerous astrocytic processes are GAT-1 positive, whereas other glial cells in the cortex or in the underlying white matter are not labeled with antibodies to GAT-1. The possibility that the GAT-1 antibodies might have cross-reacted with GAT-3, which is expressed by astrocytes in culture (Borden et al., 1994b) and by Muller cells (Johnson et al., 1995, unpublished observations) can be excluded, since preadsorbing GAT-1 antibodies with GAT3 $3_{607-627}$ did not abolish astrocytic immunoreactivity. However, we can not rule out the possibility that GAT-1 antibodies may have cross-reacted with other unidentified membrane proteins. The immunocytochemical observations are, however, supported by GFAP/GAT-1 mRNA double labeling experiments, which showed that some GFAP-positive cells express GAT-1 mRNA.

GAT-1 expression in glial cells has also been reported in retinal Muller cells (Brecha and Weigmann, 1994; Johnson et al., 1995 , unpublished observations), in hippocampal astrocytic processes (Ribak and Brecha, 1994; C. F. Ribak, W. Tong, and N. C. Brecha, unpublished observations), and in the electromotor nucleus of Torpedo (Swanson et al., 1994). Together, these observations show that GAT-1 is expressed by neurons and astrocytes, in contrast to previous suggestions that neurons and astrocytes express different GABA transporters (Iversen and Kelly, 1975; Mabjeesh et al., 1992). The present observations also extend earlier studies that indicated that "neuronal" and "glial" GABA transporters are not always separable on the basis of pharmacological criteria (Cummins et al., 1982; Levi et al., 1983; Reynolds and Herschowitz, 1986). Interestingly, Clark et al. (1992) showed that mRNAs encoding for GAT-3, a presumed "glial" GABA transporter, are expressed also in brainstem neurons.

\section{GAT- 1 expression in cortical neurons and axon terminals}

Overall, the distribution pattern of neurons expressing GAT-1 is reminiscent of that of GAD- or GABA-immunoreactive neurons, although the number cells expressing GAT-1 mRNA appears higher than that of GAD- or GABA-positive neurons. Doublelabeling experiments in which GAD67 ICC has been combined with GAT-1 ISH showed that (1) all GAD67-positive cells contained GAT-1 mRNA, and (2) some GAD67 negative cells, belonging to both the nonpyramidal and the pyramidal classes of cortical neurons, are associated with an above-background number of silver grains. Since we used the polyclonal antiserum K2 (Kaufman et al., 1991) that recognizes primarily GAD67, it is possible that some GAT-1 positive/GAD67 negative neurons contain GAD65 or that GABA synthesis is mediated by other 

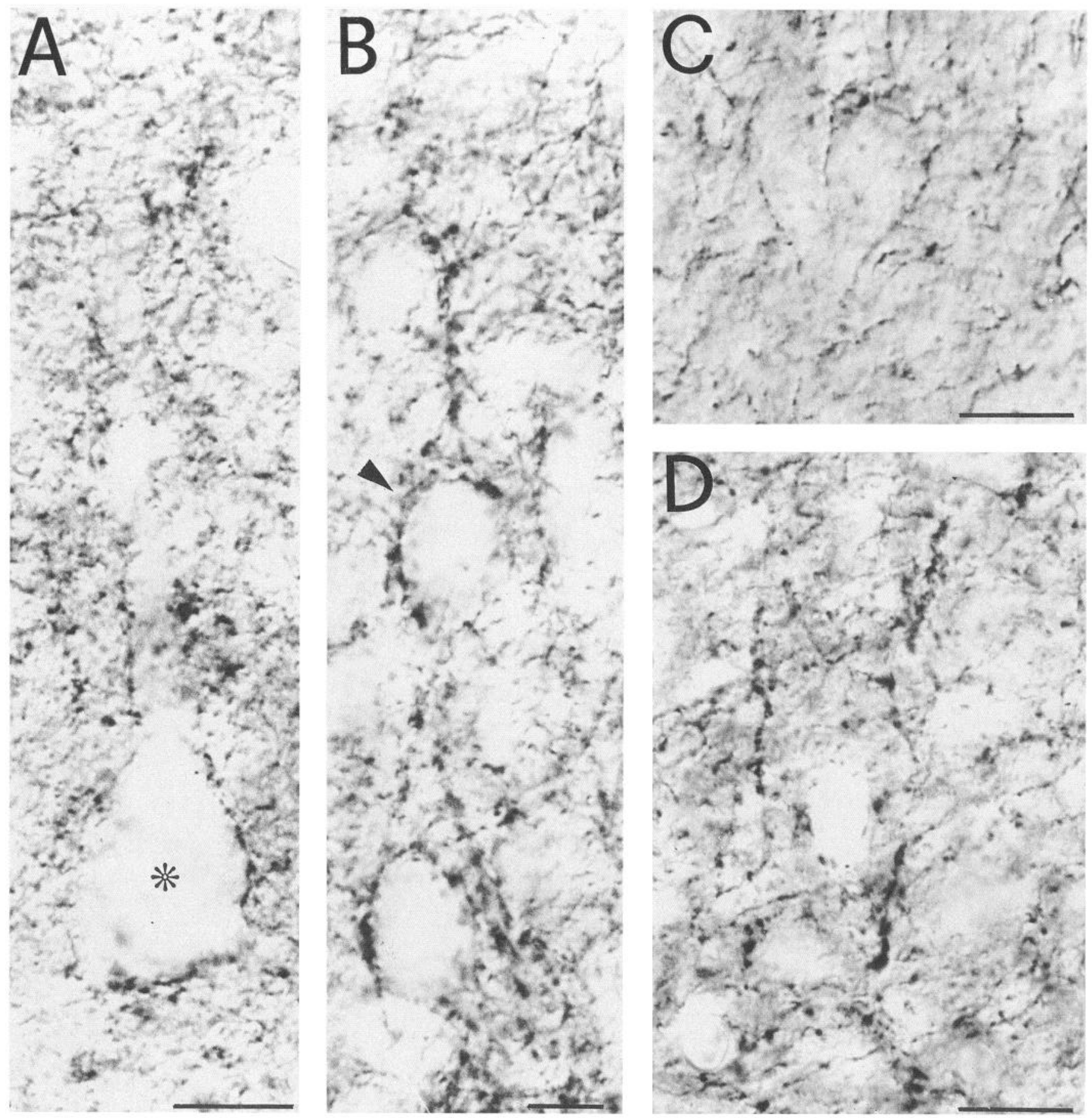

Figure 8. GAT-1 immunoreactivity within punctate structures that represent probable axon terminals $(A$ and $B)$ and in some fibers $(C$ and $D)$. The cell bodies and primary dendrites of both pyramidal (asterisk) and nonpyramidal (arrowhead) cells are outlined by stained axon terminals. Scale bars: $A, 15 \mu \mathrm{m} ; B, 10 \mu \mathrm{m} ; C$ and $D, 20 \mu \mathrm{m}$.

enzymes (Erdo, 1985). Whereas this explanation may account for the labeling of nonpyramidal GAT-1 positive/GAD67 negative neurons, it does not account for GAT-1 mRNA containing pyramidal cells, in which GABAergic markers have never been reported. The observation that some pyramidal neurons express GAT-1 mRNA, therefore, shows that at least some nonGABAergic neurons do indeed express GAT-1, a finding that implies the existence of a postsynaptic GABA transporter. The functional significance of this observation remains to be estab- lished for these cells; for instance, the presence of GAT-1 on the dendrites and soma of these cell bodies would be functionally important, since GABA exerts most of its action at these sites on pyramidal neurons (DeFelipe and Farinas, 1992). The present finding that some neurons express transporters for neurotransmitters different from those released by their axon terminals is in line with the results of a recent ICC study, which showed that one of the recently cloned glutamate transporters, EAAC1 (Kanai et al., 1994), is not confined to glutamatergic 

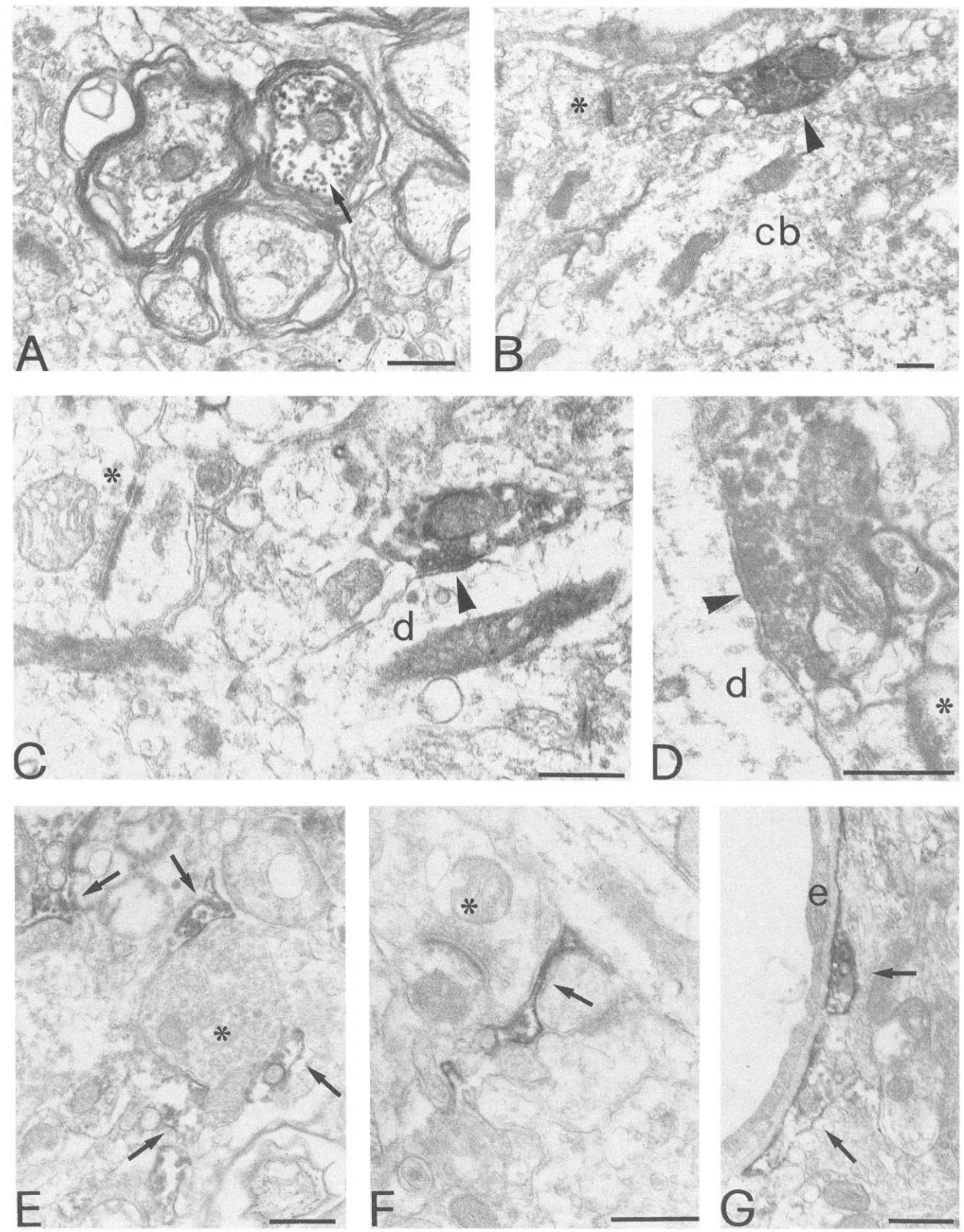

Figure 9. Ultrastructural localization of GAT-1-ir in the cerebral cortex. A, Reaction product in the axoplasm of a myelinated fiber (arrow). B$D$, GAT-1-ir in axon terminals with symmetric specialization. The labeled terminal in $B$ synapses (arrowhead) on an unlabeled cell body ( $c b$ ), whereas the labeled terminals in $C$ and $D$ synapse (arrowhead) on unlabeled dendrites $(d)$. Adjacent terminals with asymmetric specialization (asterisks) are unlabeled. $E-G$, GAT-1-ir in astrocytic processes. $E-F$, Labeled thin astrocytic processes (arrows) scattered in the neuropil among unlabeled terminals (asterisks) and other neuronal profiles. $G$, labeled perivascular astrocytes (arrowhead) beneath the endothelial cells $(E$ ). $A-D$, Lead citrate counterstaining; $E-G$, Uncounterstained sections. Scale bars, $0.5 \mu \mathrm{m}$. 
neurons, but is also present in nonglutamatergic neurons, such as Purkinje cells (Rothstein et al., 1994).

The morphology, laminar distribution and synaptic relationships of GAT-1 positive axon terminals is similar to that reported for GAD- and GABA-positive axon terminals (Ribak, 1978; Houscr et al., 1984). GAT-1 positive puncta were not quantified, but they seem to be more numerous than GAD67-positive puncta. This difference may be due to the fact that GAT-1 is a more robust marker of GABAergic axon terminals than GAD67, or may simply reflect the higher number of GAT-1-positive neurons than that of GAD67-positive neurons.

The large majority of axon terminals forming symmetric synapses on pyranidal and nompyramidal neocortical neurons arise from several types of nonpyramidal cells, including smooth and sparsely spinous neurons with local plexus axons, and basket, chandelier, and double-bouquet cells (Peters, 1987), which have been shown to be GABAergic (Somogyi and Martin, 1985; Hendry and Carder, 1992; Jones, 1993, for reviews; and Kisvarday et al., 1990, for data on human cerebral cortex). In addition, axon terminals from basal forebrain GABAergic neurons form symmetric synapses in the neocortex (Freund and Meskenaite, 1992). These observations provide further support to the suggestion that a large proportion of neurons and axon terminals expressing GAT-1 mRNA corresponds to GABAergic neurons and synapses.

All pyramidal neuron axon terminals form synapses of the asymmetric type (Winfield et al., 1981; McGuire et al., 1984); since a few of these cells contain GAT-1 mRNA, some asymmetric synapses may also contain GAT-1. However, GAT-1 immunoreactivity was not detected in axon terminals forming asymmetric synapses. This may be due to the presence of GAT-1 levels below the threshold for immunocytochemical detection or may reflect the paucity of such terminals.

\section{GAT-1-mediated GABA uptake system in the cerebral cortex: correlation with $G A D$-containing system and functional implications}

The major conclusion that emerges from the present study is that in the cerebral cortex the GABA uptake system mediated by GAT-1 is strongly expressed and that it is more extensive than the GABA synthetizing system. This conclusion raises two issues bearing on the proposed cell specificity of neurotransmitter transporters and on the function(s) of $\mathrm{GABA}$ and $\mathrm{GABA}$ transporters in the cerebral cortex.

First, early studies on the localization of ncurotransmitter transporters emphasized the coincidence between their distribution and that of synthetizing enzymes or other markers for the same transmitters, and led therefore to the notion of cell specificity of neurotransmitter transporters (Uhl, 1992). The present evidence shows that the distribution of one such transporter, GAT-1, is indeed largely coincident with that of other GABAergic markers, but at the same tine argues against a dogmatic view of cell specificity or limits it to other neurotransmitter transporter systems (Uhl, 1992), since we have shown that GAT1, a "neuronal" transporter, is localized to both neurons and glia, and that neurons expressing GAT-1 are heterogeneous in terms of morphology, transmitter phenotype, and function (see also Bonanno and Raiteri, 1992; Kimelberg, 1992).

Second, the present evidence that most GAT-1 is expressed in axon terminals forming symmetric synapses is in agreement with the classical notion that the main function of GABA transporters, like other neurotransmitter transporters, is to reaccu- mulate released transmitters into presynaptic terminals and vesicles, thus aiding at terminating the overall process of synaptic transmission and contributing to transmitter recycling into synaptic vesicles. This localization is also consistent with the possible $\mathrm{Ca}^{2+}$-independent, nonvesicular, release of GABA during synaptic activity or depolarization (Attwel et al., 1993). In addition, the localization of GAT-1 to axon terminals and astrocytic processes fits with several physiological studies that suggest that GABA uptake regulates GABA action at its receptors, and that GABA acts in a "paracrine" manner on presynaptic G-protein-coupled $\mathrm{GABA}_{\mathrm{B}}$ receptors located on excitatory axon terminals (Dingledine and Korn, 1985; Thompson and Gahwiler, 1992; Isaacson et al., 1993). Interestingly, the GABA uptake inhibitors tiagabine and SKF-89976A, which are specific for GAT-1 (Borden et al., 1994b), selectively enhances the presynaptic action of GABA on presumed $\mathrm{GABA}_{B}$ receptors on excitatory nerve terminals (Thompson and Gahwiler, 1992; Isaacson et al., 1993). Since a few pyramidal neurons express GAT-1 mRNA, it is possible that GAT-1 is on axon terminals that release glutamate or another excitatory amino acid (Conti et al., 1987, 1989; DeFelipe et al., 1988; Dori et al., 1989).

\section{References}

Attwell D, Barbour B, Szatkowski M (1993) Nonvesicular release of neurotransmitter. Neuron 11:401-407.

Beart PM, Johnston GAR, Uhr ML (1972) Competitive inhibition of GABA uptake in rat brain slices by some GABA analogues of restricted conformation. J Neurochem 19:1855-1861.

Beaulieu C (1993) Numerical data on neurons in adult rat neocortex with special reference to the GABA population. Brain Res 609:284292.

Bignami A, Dahl D (1973) Astrocyte-specific protein and neuroglial differentiation. An immunofluorescence study with antibodies to the glial fibrillary acidic protein. J Comp Neurol 153:27-38.

Bloom FE, Iversen LL (1970) Localizing ${ }^{3} \mathrm{H}-\mathrm{GABA}$ in nerve terminals of rat cerebral cortex by electron microscopic autoradiography. $\mathrm{Na}$ ture 229:628-630.

Bonanno G, Raitcri M (1992) Arc neurotransmitter carriers cell-spe cific markers? Trends Neurosci 15:482.

Borden LA, Smith KE, Hartig PR, Brancheck TA, Weinshank RL (1992) Molecular heterogeneity of the $\gamma$-aminobutyric acid (GABA) transport system. J Biol Chem 267:21098-21104.

Borden LA, Smith KE, Vaysse PJ-J, Weinshank RL, Branchek TA (1994a) GABA transporters in neuronal and glial cell cultures: correlation of pharmacological activity with mRNA localization. Soc Neurosci Abstr 20:919.

Borden LA, Murali Dhar TG, Smith KE, Weinshank RL, Branchek TA, Gluchowski C (1994b) Tiagabine, SK\&F 89976-A,CI-966, and NCC-711 are selective for the cloned GABA transporter GAT-1. Fur J Pharmacol 269:219-224.

Bowery NG, Jones GP, Neal MJ (1976) Selective inhibition of neuronal GABA uptake by cis-1,3-aminocyclohexane carboxylic acid $(\Lambda \mathrm{CHC}$ ). Nature 264:281-284.

Brecha NC, Weigmann C (1994) Expression of GAT-1, a high affinity gamma-aminobutyric acid plasma membrane transporter in the rat retina. J Comp Neurol 345:602-611.

Brecha NC, Sternini C, Anderson K, Krause JE (1989) Expression and cellular localization of substance P/neurokinin B mRNAs in the rat brain. Visual Neurosci 3:527-535.

Brecha NC, Weigman C, Messersmith E (1992) Expression of GABA transporter mRNA in the rat central nervous system. Soc Neurosci Abstr 18:473.

Brecha NC, Casini G, Fvans C, Rickman D (1993) Localization of GABA transporter (GAT-1) immunoreactivity in the rat nervous system. Soc Neurosci Abstr 19:496.

Brecha NC, Johnson J, Chen T, Conti F, Minelli A, DeBiasi S, Ribak C (1995) GABA transporter expression in the rat nervous system. Paper presented at the conference on presynaptic mechanisms of neurotransinission, San Diego, CA, 9-11 November 1995 (abstract).

Chapin JK, Lin C-S (1990) The somatic sensory cortex of the rat. In: 
The cerebral cortex of the rat (Kolb B, Tees RG, eds), pp 341-380. Cambridge, MA: MIT Press.

Clark JA, Amara SG (1994) Stable expression of a neuronal $\gamma$-aminobutyric acid transporter, GAT-3, in mammalian cells demonstrates unique pharmacological properties and ion dependence. Mol Pharmacol 46:550-557.

Clark JA, Deutch AY, Gallipoli PZ, Amara SG (1992) Functional expression and CNS distribution of a $\beta$-alanine-sensitive neuronal GABA transporter. Neuron 9:337-348.

Conti F, Rustioni A, Petrusz P, Towle AC (1987) Glutamate-positive neurons in the somatic sensory cortex of rats and monkeys. J Neurosci 7:1887-1901.

Conti F, DeFelipe J, Farinas I, Manzoni T (1989) Glutamatc-positive neurons and axon terminals in cat sensory cortex: a correlative light and electron microscopic study. J Comp Neurol 290:141-153.

Conti F, Minelli A, Molnar M, Brecha NC (1994a) Cellular localization and laminar distribution of NMDAR1 mRNA in the rat cerebral cortex. J Comp Neurol 343:554-565.

Conti F, Minelli A, Brecha NC (1994b) Cellular localization and laminar distribution of AMPA glutamate receptor subunits mRNAs and proteins in the rat cerebral cortex. I Comp Neurol 350:241-259.

Cox KH, DeLeon DV, Angerer LM, Angerer RC (1984) Detection of mRNAs in sea urchin by in situ hybridization using asymmetric RNA probes. Dev Biol 101:485-502.

Cummins CJ, Glover RA, Sellinger OZ (1982) Beta-alanine uptake is not a marker for brain astroglia in culture. Brain Res 239:299-302.

deBlas AL, Vitorica J, Friedrich P (1988) Localization of the GABA receptor in the rat brain with a monoclonal antibody to the 57,000 $\mathrm{M}_{\mathrm{T}}$ peptide of the $\mathrm{GABA}_{\mathrm{A}}$ receptor/benzodiazepine receptor/Cl channel complex. J Neurosci 8:600-614.

DeFelipe J, Farinas I (1992) The pyamidal neuron of the cerebral cortex: morphological and chemical characteristics of the synaptic inputs. Prog Neurobiol 39:563-607.

DeFelipe J, Conti F, Van Eyck SL, Manzoni T (1988) Demonstration of glutamate-positive axon terminals forming asymmetrical synapses in the cat neocortex. Brain Res 455:162-165.

Dingledine R, Korn SJ (1985) $\gamma$-Aminobutyric acid uptake and the termination of inhibitory synaptic potentials in the rat hippocampal slice. J Physiol (Lond) 366:387-409.

Dori I, Petrou M, Parnavelas JG (1989) Excitatory transmitter amino acid containing neurons in the rat visual cortex: a light and electron microscopic immunocytochemical study. J Comp Neurol 290:169. 184.

Emson PC, Hunt SP (1981) Anatomical chemistry of the cerebral cortex. In: The organization of the cerebral cortex (Schmitt FO, Worden FG, Adelman G, Dennis SG, eds), pp 325-345. Cambridge, MA MIT Press.

Eng LF (1971) An acidic protein isolated from fibrous astrocytes. Brain Res 28:351-354.

Erdo S (1985) Peripheral GABAergic mechanisms. Trends Pharmacol Sci 6:205-208.

Erlander MG, Tillakaratne NJK, Felblum S, Patel N, Tobin AJ (1991) Two genes encode distinct glutamate decarboxylases. Neuron 7:91100.

Esclapez ME, Tillakaratne JK, Kaufman DL, Tobin AJ, Houser CR (1994) Comparative localization of two forms of glutamic acid decarboxylase and their mRNAs in rat brain supports the concept of functional differences between the forms. J Neurosci 14:1834-1855.

Fitzpatrick D, Lund JS, Schmechel DE, Towle AC (1987) Distribution of GAB $\Lambda$ ergic neurons and axon terminals in the macaque striate cortex. J Comp Neurol 264:73-91.

Freund TF, Meskenaite V (1992) $\gamma$-Aminobutyric acid-containing basa forebrain neurons innervate inhibitory interneurons in the neocortex. Proc Natl Acad Sci USA 89:738-742.

Gavrilovic J, Raff M, Cohen J (1984) GABA uptake by purified rat Schwann cells in culture. Brain Res 303:183-185.

Gu Q, Peréz-Velasquez JL, Angelides KJ, Cynader MS (1993) Immunocytochemical study of $\mathrm{GABA}_{\mathrm{A}}$ receptors in the cat visual cortex. J Comp Neurol 333:94-108.

Guastella J, Nelson N, Nelson H, Czyzyk L, Keynan S, Miedel MC, Davidson N, Lester HA, Kanner BI (1990) Cloning and expression of a rat brain GABA transporter. Science 249:1303-1306.

Guastella J, Brecha NC, Weigman C, Lester HA, Davidson N (1992) Cloning, expression, and localization of a rat brain high-affinity glycine transporter. Proc Natl Acad Sci USA 89:7189-7193.
Hendry SHC, Carder RK (1992) Organization and plasticity of GABA neurons and receptors in monkey visual corlex. In: Progress in brain research, Vol 40 (Mize RR, Marc RE, Sillito AM, eds), pp 477-502. Amsterdam: Elsevier.

Hendry SHC, Jones EG, Schwark HD, Yang J (1987) Numbers and proportions of GABA immunoreactive neurons in different areas of monkey cerebral cortex. J Neurosci 7:1503-1519.

Hendry SHC, Fuchs J, deBlas AL, Jones EG (1990) Distribution and plasticity of immunocytochemically localized $\mathrm{GABA}_{\mathrm{A}}$ receptors in adult monkey visual cortex. J Neurosci 10:2438-2450.

Herrera DG, Cuello AC (1992) Glial fibrillary acidic protein immunoreactivity following cortical devascularization. Neuroscience 49: 781-791.

Hokfelt T, Ljungdahl A (1972) Autoradiographic identification of cerebral and cerebellar cortical neurons acumulating labeled gammaaminobutyric acid ( $\left.{ }^{3} \mathrm{H}-\mathrm{GABA}\right)$. Exp Brain Res 14:354-362.

Houser CR, Hendry SHC, Jones EG, Vaughn JE (1983) Morphological diversity of immunocytochemically identified GABA neurons in the monkey sensory-motor cortex. J Neurocytol 12:617-638.

Houser CR, Vaughn JE, Hendry SHC, Jones EG, Peters A (1984) GABA neurons in the cerebral cortex. In: Cerebral cortex, Vol 2, Functional properties of cortical cells (Jones EG, Peters A, eds), pp 63-90. New York: Plenum

Hsu SM, Raine L, Fanger H (1981) Use of avidin-biotin-peroxidase complex $(\mathrm{ABC})$ in immunoperoxidase techniques: A comparison between $\mathrm{ABC}$ and unlabelled antibody (PAP) procedures. J Histochem Cytochem 29:557-580.

Huntley GW, deBlas AL, Jones EG (1990) GABA A $_{A}$ receptor immunoreactivity in adult and developing monkey sensory-motor cortex. Exp Brain Res 82:519-535.

Huntsman MM, Isackson PJ, Jones EG (1994) Lamina-specific expression and activity-dependent regulation of seven $\mathrm{GABA}_{\mathrm{A}}$ receptor subunit mRNAs in monkey visual cortex. J Neurosci 14:2236-2259.

Ikegaki N, Saito N, Hashima M, Tanaka C (1994) Production of specific antibodies against GABA transporter subtypes (GAT1, GAT2, GAT3) and their application to immunocytochemistry. Mol Brain Res 26:47-54

Isaacson JS, Solis JM, Nicoll RA (1993) Local and diffuse synaptic actions of GABA in the hippocampus. Neuron 10:165-175.

Iversen LL, Kelly JS (1975) Uptake and metabolism of $\gamma$-aminobutyric acid by neurons and glial cells. Biochem Pharmacol 24:933-938.

Iversen LL (1971) Role of transmitter uptake mechanisms in synaptic neurotransmission. Br J Pharmacol 41:571-591.

Iversen LL, Neal MJ (1968) The uptake of $\left[{ }^{3} \mathrm{H}\right] \mathrm{GABA}$ by slices of rat cerebral cortex. J Neurochem 15:1141-1149.

Iversen LL, Snyder SH (1968) Synaptosomes: Different populations storing catecholamines and gamma-aminobutyric acid in homogenates of rat brain. Nature 220:796-798.

Jones EG (1993) GABAergic neurons and their role in cortical plasticity. Cereb Cortex 3:361-372.

Kanai Y, Smith CP, Hediger MA (1994) A new family of neurotransmitter tranporters: the high affinity glutamate transporters. FASEB $J$ $8: 1450-1459$

Kanner BI (1978) Active transport of $\gamma$-aminobutyric acid by membrane vesicles isolated from rat brain. Biochemistry 17:1207-1211.

Kanner BI, Bendahan A (1990) Two pharmacologically distinct sodium- and chloride-coupled high-aftinity $\gamma$-aminobutyric acid transporters are present in plasma membrane vesicles and reconstituted preparations from rat brain. Proc Natl Acad Sci USA 87:2550-2554.

Kanner BI, Shuldiner S (1987) Mechanism of transport and storage of neurotransmitters. CRC Crit Rev Biochem 22:1-39.

Kaufman DL, Houser CR, Tobin AJ (1991) Two forms of the gammaaminobutyric acid synthetic enzyme glutamate decarboxylase have distinct intraneuronal distributions and cofactor interactions. J Neurochem $56: 720-723$.

Keynan S, Suh Y-J, Kanner BI, Rudnick G (1992) Expression of a cloned $\gamma$-aminobutyric acid transporter in mammalian cells. Biochemistry 31:1974-1979.

Kimelberg H (1992) Are neurotransmitter carriers cell-specific markers? Trends Neurosci 15:482-483.

Kisvarday ZF, Gulyas A, Beroukas D, North JB, Chubb IW, Somogyi P (1990) Synapses, axonal and dendritic patterns of GABA-immunoreactive neurons in human cerebral cortex. Brain 113:793-812.

Krnjevic K (1984) Neurotransmitters in cerebral cortex: a general ac- 
count. In: Cerebral cortex, Vol 2, Functional properties of cortical cells (Peters A, Jones EG, eds), pp 39-61. New York: Plenum.

Kruger L, Ghosdian S, Brecha NC (1994) Distribution of GABA transporter (GAT-1) mRNA and immunoreactivity in the rat visual system. Soc Neurosci Abstr 20:919.

Larsson OM, Johnston GAR, Schousboe A (1983) Differences in uptake kinetics of cis-3-aminocyclohexane carboxylic acid into neurons and astrocytes in primary cultures. Brain Res 260:279-285.

Levi G, Raiteri M (1993) Carrier-mediated release of neurotransmitters. Trends Neurosci 16:415-418.

Levi G, Wilkin GP, Ciotti MT, Johnstone S (1983) Enrichment of differentiated, stellate astrocytes in cerebellar interneuron cultures as studied by GFAP immunofluorescence and autoradiographic uptake patterns with $\left[{ }^{3} \mathrm{H}\right] \mathrm{D}$-aspartate and $\left[{ }^{3} \mathrm{H}\right] \mathrm{GABA}$. Dev Brain Res 10:227241.

Liu Q-R, Lopez-Caarcuera B, Mandiyan S, Nelson H, Nelson N (1993) Molecular characterization of four pharmacologically distinct $\gamma$-aminobutyric acid transporters in mouse brain. J Biol Chem 268:21062112.

Mabjeesh NJ, Frese M, Rauen T, Jeserich G, Kanner Bi (1992) Neuronal and glial $\gamma$-aminobutyric acid transporters are distinct proteins FEBS Lett 299:99-102.

Mager S, Naeve J, Quick M, Labarca C, Davidson N, Lester H (1993) Steady states, charge movement, and rates for a cloned GABA transporter expressed in Xenopus oocytes. Neuron 10:177-188.

McCormick DA, Wang Z, Huguenard J (1993) Neurotransmitter control of neocortical neuronal activity and excitability. Cereb Cortex $3: 387-398$

McGuire BD, Hornung JP, Gilbert C, Wiesel T (1984) Patterns of synaptic input to layer 4 of striate cortex. J Neurosci 4:3021-3033.

Minelli A, Brecha NC, Conti F (1993) Expression of high-affinity GABA transporter mRNA in the rat somatic sensory cortex. Abstr XLV Meet Ital Physiol Soc 125.

Neal MJ, Iversen LL (1969) Subcellular distribution of endogenous and $\left[{ }^{3} \mathrm{H}\right] \gamma$-aminobutyric acid in rat cerebral cortex. J Neurochem 16 $1245-1252$.

Peters A (1987) Synaptic specificity in the cerebral cortex. In: Synaptic function (Edelman G, Gall E, Cowan M, eds), pp 373-397. New York: Wiley.

Pin J-P, Bockaert J (1989) Two distinct mechanisms, differentially afrected by excilatory amino acids, trigger GABA release from fetal mouse striatal neurons in primary culture. J Neurosci 9:648-656.

Radian R, Ottersen OP, Storm-Mathisen J, Castel M, Kanner BI (1990) Immunocytochemical localization of the GABA transporter in rat brain. J Neurosci 10:1319-1330.

Reynolds R, Herschowitz N (1986) Selective uptake of neuroactive amino acids by both oligodendrocytes and astrocytes in primary dissociated cell culture: a possible role for oligodendrocytes in neurotransmitter metaholism. Brain Res 371:253-266.

Ribak CE (1978) Aspinous and sparsely-spinous stellate neurons in the visual cortex of rat contain glutamic acid decarboxylase. J Neurocytol 7:461 478 .

Ribak CE, Brecha NC (1994) The immunocytochemical localization of the GAT-1 transporter in the rat dentate gyrus. Soc Neurosci Abstr 20:349.

Rothstein JD, Martin L, Levey AI, Dykes-Hoberg M, Jin L, Wu D, Nash M, Kuncl RW (1994) Localization of neuronal and glial glutamate transporters. Neuron 13:713-725.

Schon F, Kelly JS (1974) The characterisation of [ $\left.{ }^{3} \mathrm{H}\right] \mathrm{GABA}$ uptake into the satellite glial cells of rat sensory ganglia. Brain Res 66:289300 .

Schousboe A (1981) Transport and metabolism of glutamate and GABA in ncurons and glial cclls. Int Rev Neurobiol 22:1-45.

Schwartz EA (1982) Calcium-independent release of GABA from isolated horizontal cells of the toad retina. J Physiol (Lond) 323:211 227.

Sillito AM (1984) Functional considerations of the operation of GABAergic inhibitory processes in the visual cortex. In: Cerebral cortex, Vol 2, Functional properties of cortical cells (Peters A, Jones EG, eds), pp 91-117. New York: Plenum.

Somogyi $\mathrm{P}$ (1989) Synaptic organization of GABAergic neurons and $\mathrm{GABA}_{\mathrm{A}}$ receptors in the lateral geniculate nucleus and visual cortex. In: Proceedings of the Retina Research Foundation, Vol 2, Neural mechanisms of visual perception (Lam DM-K, Gilbert CD, eds), pp 35-62. Cambridge, MA: MIT Press.

Somogyi P, Martin KAC (1985) Cortical circuitry underlying inhibitory processes in cat area 17. In: Models of the visual cortex (Rose D, Dobson VG, eds), pp 514-523. Chichester: Wiley.

Sternini C, Anderson K, Frantz G, Krause JE, Brecha NC (1989) Expression of substance P/neurokinin A-encoding preprotachykinin mRNAs in the rat enteric nervous system. Gastroenterology 97:348356.

Swan M, Najlerahim A, Watson REB, Bennett JP (1994) Distribution of mRNA for the GABA transporter GAT-1 in the rat brain: evidence that GABA uptake is not limited to presynaptic neurons. J Anat 185: 315-323.

Swanson GT, Umbach JA, Gundersen CB (1994) Glia of the cholinergic electromotor nucleus of Torpedo are the source of the cDNA encoding a GAT-1-like GABA transporter. J Neurochem 63:1-12.

Thompson SM, Gahwiler BH (1992) Effects of the GABA uptake inhibitor tiagabine on inhibitory synaptic potentials in rat hippocampal slice cultures. J Neurophysiol 67:1698-1670.

Uhl G (1992) Neurotransmitter transporters (plus): a promising new gene family. Trends Neurosci 15:265-268.

Winfield DA, Brooke RNL, Sloper JJ, Powell TPS (1981) A combined Golgi-electron micorscopic study of the synapses made by the proximal axon and recurrent collaterals of a pyramidal cell in the somatic sensory cortex of the monkey. Neuroscience 6:1217-1230.

Wisden W, Laurie DJ, Monyer H, Seeburg PH (1992) The distribution of $13 \mathrm{GABA}_{\mathrm{A}}$ receptor subunit mRNAs in the rat brain. I. Telencephalon, diencephalon, mesencephalon. J Neurosci 12:1040-1062.

Yamauchi A, Uchida S, Kwon HM, Preston AS, Robey RB, GarciaPerez A, Burg MB, Handler JS (1992) Cloning of a $\mathrm{Na}^{+}$- and $\mathrm{Cl}^{-}$dependent betaine transporter that is regulated by hypertonicity. $\mathbf{J}$ Biol Chem 267:649 652.

Zilles K (1985) The cortex of the rat. Berlin: Springer. 